\title{
Natural killer activity of the spleen cells of Ehrlich tumor-bearing mice treated with Copaifera multijuga extract
}

\author{
Atividade natural killer das células esplênicas de camundongos portadores \\ do tumor de Ehrlich tratados com extrato de Copaifera multijuga
}

\author{
Paloma Filomena Gouveia Rodrigues (D) 1, Lucinéia Reuse Albiero (D) 1, Eduardo Figueredo Nery (D) 1, \\ Taiany Oliveira Kelly (D) 1, Jeniffer Charlene Silva Dalazen (D) 1, Débora Linsbinski Pereira (D) 1, Adilson Paulo Sinhorin (D) 2 ,
} Valéria Dornelles Gindri Sinhorin (iD) ${ }^{2}$, Lindsey Castoldi (D) ${ }^{1} \bowtie$

Health Sciences Institute, Federal University of Mato Grosso. Sinop, Mato Grosso, Brazil

2 Natural, Human, and Social Sciences Institute, Federal University of Mato Grosso. Sinop, Mato Grosso, Brazil

How to cite this article:

Rodrigues PFG, Albiero LR, Nery EF, Kelly TO, Dalazen JCS, Pereira DL, Sinhorin AP, Sinhorin VDG, Castoldi L. Natural killer activity of the spleen cells of Ehrlich tumor-bearing mice treated with Copaifera multijuga extract. Sci Med. 2019;29(1):e32408. https://doi.org/ $10.15448 / 1980-6108.2019 .1 .32408$

\section{ABSTRACT}

AIMS: Copaifera multijuga Hayne oleoresin is commonly used in traditional medicine owing to its anti-inflammatory, antiseptic, antitumor, and antibacterial properties. However, little is known about the effect of the compounds from the bark of this plant. In this study, the immunomodulatory effect of the ethanolic extract of $C$. multijuga bark via natural killer activity of non-adherent spleen cells of Ehrlich tumor-bearing mice was evaluated.

METHODS: Male Swiss mice were inoculated subcutaneously with $1 \times 10^{6}$ Ehrlich tumor cells (Ehrlich and Ehrlich/C. multijuga group) or phosphate buffered saline solution (control group and C. multijuga group) and treated orally daily with C. multijuga extract (200 mg kg- ${ }^{-1}$, $0.1 \mathrm{~mL}$ per mouse, for the Ehrlich/C. multijuga and C. multijuga groups) or phosphate buffered saline solution (control group and Ehrlich group). The four experimental groups consisted in eight mice each and were organized in two sets, one treated for seven days and another treated for 14 days, totalizing 64 mice throughout the experiment. Twenty-four hours after the last oral administration, the mice were euthanized and the spleen tissue was isolated to prepare a non-adherent spleen cell suspension and to evaluate natural killer activity. Data are presented as the cell lysis percentage of Yac. 1 target cells by non-adherent spleen cells.

RESULTS: Treatment for seven days increased natural killer activity in the Ehrlich/C. multijuga group $(21.20 \pm 8.89, \mathrm{p}<0.05)$ compared to the control group $(3.14 \pm 2.71, \mathrm{p}<0.05)$; however, this effect was not maintained in the groups treated for 14 days (Control: $6.02 \pm 6.98$, Ehrlich: 4.82 \pm 7.72 , C. multijuga: $2.07 \pm 2.10$, Ehrlich/C. multijuga: $2.01 \pm 1.63, \mathrm{p}>0.05$ ).

CONCLUSIONS: Treatment for seven days with an ethanolic extract of $C$. multijuga bark enhanced the natural killer activity of non-adherent spleen cells from Ehrlich tumor-bearing mice.

KEYWORDS: Copaifera multijuga; fabaceae; copaiba; natural killer cells; carcinoma, Ehrlich tumor; immunomodulation.

\section{RESUMO}

OBJETIVOS: O óleo-resina de Copaifera multijuga Hayne é popularmente utilizado na medicina tradicional por suas propriedades antiinflamatória, antisséptica, antitumoral e antibacteriana. Entretanto, há poucos estudos sobre o efeito dos compostos obtidos da casca da planta. Assim, o objetivo deste trabalho foi avaliar o efeito imunomodulador do extrato etanólico da casca da C. multijuga na atividade natural killer das células esplênicas não aderentes de animais portadores do tumor de Ehrlich.

MÉTODOS: Camundongos Swiss machos foram inoculados subcutaneamente com $1 \times 10^{6}$ células do tumor de Ehrlich (grupo Ehrlich e Ehrlich/C. multijuga) ou com solução salina tamponada (grupo controle e C. multijuga) e tratados diariamente (gavagem) com extrato de C. multijuga (200 $\mathrm{mg} \mathrm{kg}^{-1}, 0,1 \mathrm{~mL}$ cada um, para os grupos Ehrlich/C. multijuga e C. multijuga) ou com solução salina tamponada (grupo controle e grupo Ehrlich). Os quatro grupos experimentais consistiram de oito animais cada e foram organizados em dois conjuntos, um tratado por sete dias e outro tratado por 14 dias, totalizando 64 animais durante todo o experimento. Após 24 horas do término do tratamento, os animais foram eutanasiados para obtenção da suspensão de células esplênicas não aderentes e avaliação da atividade natural killer. Os resultados são apresentados como porcentagem da lise celular das células alvo Yac.1 pelas células esplênicas não aderentes.

RESULTADOS: A análise dos resultados demonstrou que aos sete dias de tratamento a C. multijuga aumentou a atividade natural killer no grupo Ehrlich/C. multijuga $(21,20 \pm 8,89, \mathrm{p}<0,05)$ em comparação ao grupo controle $(3,14 \pm 2,71, \mathrm{p}<0,05)$, entretanto tal efeito não foi mantido

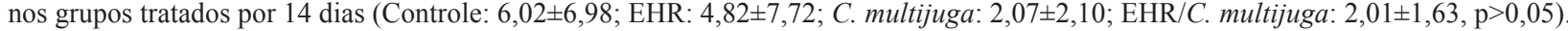

CONCLUSÕES: Os resultados demonstraram que o tratamento com o extrato etanólico da casca de C. multijuga favoreceu a atividade natural killer das células esplênicas não aderentes dos animais portadores do tumor de Ehrlich apenas aos sete dias de tratamento.

DESCRITORES: Copaifera multijuga; fabaceae; copaíba; células natural killer; carcinoma de Ehrlich; imunomodulação. 
Abbreviations: ABAM, Biological Collection of Southern Amazonia (Acervo Biológico da Amazônia Meridional); C. multijuga, Copaifera multijuga; Con A, concanavalin A; FBS, heat-inactivated fetal bovine serum; IFN- $\gamma$, interferon-gamma; IL-12p70, interleukin-12p70; LDH, lactate dehydrogenase; NK, natural killer; PBS, phosphate buffered saline; RPMI, Roswell Park Memorial Institute; SAC, Saccharomyces cerevisiae; TNF- $\alpha$, tumor necrosis factor-alfa; UFMT, Federal University of Mato Grosso (Universidade Federal de Mato Grosso).

\section{INTRODUCTION}

Phytotherapeutic compounds have been widely used due to their efficiency, low toxicity, biocompatibility and low cost [1]. Since 2002, the World Health Organization has recognized the importance of phytotherapeutic compounds used in traditional medicine as part of conventional healthcare strategies [2]. In Brazil, the National Policy of Medicinal Plants and Herbal Medicines encourages the development of plant-based compounds for use in public health programs [2].

In this context, copaiba has been one of the most important Brazilian medicinal plants [1-6]. As early as 1587, the Portuguese explorer and naturalist Gabriel Soares de Sousa described the use of copaiba oleoresin for healing arrow wounds [2]. Nowadays, copaiba is used in medicine owing to its anti-inflammatory, antibacterial, antifungal, leishmanicidal, antitumor, and analgesic properties [1-5, 7-9].

Copaiba trees belong to the genus Copaifera, family Fabaceae, and subfamily Caesalpinioideae [6]. There are more than 70 Copaifera species distributed worldwide, with widespread occurrence in Central and South America, but also in West Africa and Asia [6]. Brazil has the greatest biodiversity of Copaifera with 26 species and 8 varieties [6]. The most abundant species are Copaifera multijuga Hayne, Copaifera reticulata, and Copaifera langsdorffii Desf. [5-7].

The oleoresin is the most important economic and medicinal product of copaiba trees [6]. It is a transparent and colored exudate obtained from the trunks of the trees, with variable viscosity, and consisting of a nonvolatile fraction of diterpenes $(20 \%)$ and a volatile fraction of sesquiterpenes (80\%) [2,5-7]. Copaiba oleoresin chemical profile may vary according to species, seasonal and climatic characteristics, soil type and composition, and biotic pressures, such as insect predation and pathogen infection [2,5-7]. The production of oleoresin per tree ranges from $100 \mathrm{~mL}$ to $60 \mathrm{~L}$ annually; however, not all trees produce oil [6]. Therefore, several parts and preparations of the plant, such as stem bark crude formulation, are used in folk medicine [6].
In previous studies by our group, it was observed that ethanolic extract of $C$. multijuga bark can affect Ehrlich tumor cells, reducing their viability in vitro as well as their development in vivo [9]. Ehrlich tumor is a spontaneous murine mammary adenocarcinoma adapted to the ascitic form and inoculated in mice by serial intraperitoneal passages $[9,10]$. This tumor model is widely used in experimental cancer studies due to its versatility; it is able to adapt to an ascitic form when inoculated by the intraperitoneal route or a solid form when inoculated by the subcutaneous route $[9,11,12]$.

The development of Ehrlich ascites tumor is commonly accompanied by intense alterations of the immune response, leading to decreased immunocompetence with down-regulation of cytotoxic cells such as natural killer (NK) cells [13]. NK cells are important effector cells of the innate immune system that play an active role in the elimination of cancerous and virus-infected cells [14]. Activation of NK cells results in their lytic granule exocytosis, with the release of perforin and granzymes against locally attached target cells; this leads to the secretion of cytokines $[13,14]$. An important feature of the NK immune response is that these cells do not require prior sensitization to exert their effector function [14].

Thus, considering the antitumor effect of $C$. multijuga bark extract on Ehrlich tumor [9] and the importance of NK cells as a strategy in cancer immunotherapy [15], the present study aimed to evaluate the immunomodulatory effect of ethanolic extracts obtained of $C$. multijuga bark on the NK activity of the non-adherent spleen cell culture of Ehrlich tumor-bearing mice.

\section{METHODS}

\section{Plant material}

The plant material was collected at a particular property in Guarantã do Norte, MT, Brazil (S 9 ${ }^{\circ} 48^{\prime}$ 31.0" W 54 $53^{\circ}$ ' 18.0"), according to Albiero et al. [9]. The specimens were identified by Professor Ivani Kuntz Gonçalves, and samples are deposited at Herbarium of Federal University of Mato Grosso (Universidade Federal de Mato Grosso, UFMT), Biological Collection of Southern Amazonia (Acervo Biológico da Amazônia Meridional, ABAM), Sinop, MT, Brazil, N.4801.

\section{Preparation of C. multijuga extracts}

C. multijuga extracts were prepared according to Albiero et al. [9]. C. multijuga bark was obtained at a 
stem depth of $5 \mathrm{~cm}$, cleaned, cut in small pieces, and air-dried at $40{ }^{\circ} \mathrm{C}$ for seven days. The dried material was processed in a crusher $(1.0 \mathrm{~mm})$ and macerated with a different solvent for each extraction phase $(2 \mathrm{~L}$ per $1,257 \mathrm{~g}$ sample). First, hexane was added and the extract was stored for seven days. Ethyl acetate was added, and it was stored for an additional seven days. Ethanol was added, and the extract was stored for seven days to complete the maceration. At each phase, the solvent was replaced, and the extract was protected from light exposure. The resulting hexane, ethyl acetate, and ethanolic extracts were filtered through a filter paper under negative pressure. A rotary vacuum evaporator (IKA ${ }^{\circledR}$ RV 05 basic, Staufen, Germany) at $40^{\circ} \mathrm{C}$ and vacuum desiccator were used to concentrate and remove the solvents. The yields obtained were $1.652 \mathrm{~g}$ for the hexane extract, $5.152 \mathrm{~g}$ for the ethyl acetate extract, and $220.463 \mathrm{~g}$ for the ethanol extract. The ethanolic extract was used for the evaluation of NK cell activity in vitro, since it obtained the highest yield and the best result with in the in vitro cytotoxicity analysis demonstrated in previous study [9].

\section{Animals}

Male Swiss mice, aged 40 to 50 days, were obtained from the Central Animal Facility of UFMT in Cuiabá, MT, Brazil. The mice were housed in polypropylene boxes at $22^{\circ} \mathrm{C}$, exposed to $12 / 12$-h light/dark cycles, and administered filtered water and pelleted feed (Purina, St. Louis, Missouri, USA) ad libitum. All procedures were approved by the Ethics Committee on Animal Use of UFMT (Protocol no. 23108.700603/14-3).

The mice were inoculated subcutaneously with $1 \times 10^{6}$ tumor cells (Ehrlich or Ehrlich/C. multijuga groups) or $100 \mu \mathrm{L}$ of phosphate buffered saline (PBS) (Control or C. multijuga groups). Twenty-four hours later, the mice were treated daily by gavage with the ethanolic extract $\left(200 \mathrm{mg} \mathrm{kg}^{-1} ; 100 \mu \mathrm{L}\right.$ per animal; for the Ehrlich/C. multijuga and C. multijuga groups) or vehicle (PBS; $100 \mu \mathrm{L}$ per animal; control and Ehrlich groups). The four experimental groups consisted in eight mice each and were organized in two sets, one treated for seven days and another treated for 14 days, totalizing 64 mice throughout the experiment. After these periods, the mice were euthanized for the in vitro evaluation of the NK activity from the spleen cell culture.

\section{Spleen cell suspensions}

Spleen cell suspensions were obtained by teasing the spleens on a sterile fine nylon screen in Roswell Park
Memorial Institute (RPMI) 1640 medium (Cultilab, Campinas, SP, Brazil). The cell suspensions were centrifuged at $1,500 \mathrm{rpm}$ for $10 \mathrm{~min}$ and suspended in $1 \mathrm{~mL}$ of complete medium (RPMI 1640 supplemented with $20 \%$ of heat-inactivated fetal bovine serum (FBS) (Cultilab, Campinas, SP, Brazil).

\section{Ehrlich tumor cell suspension}

Ehrlich tumor was provided by Rondon Tosta Ramalho, Ph.D., from the Federal University of Mato Grosso do Sul, Campo Grande, Brazil and was maintained through intraperitoneal inoculation (ascitic form) in Swiss mice, every seven days. Tumor cell suspensions were prepared in sterile PBS, to final concentration of $1 \times 10^{7}$ viable cells $\mathrm{mL}^{-1}$. The mice were inoculated subcutaneously in the right flank region $(0.1 \mathrm{~mL}$ per animal). Viability, assessed by Trypan Blue dye exclusion method, was at least $70 \%$.

\section{Yac.1 Target Cell Suspension}

Yac.1 mouse lymphoma cell line, an NK-sensitive tumor cell line, was provided by Rio de Janeiro Cell Bank. Aliquots of Yac. 1 cells were cultured in complete medium at $37^{\circ} \mathrm{C}$ and $5 \% \mathrm{CO}_{2}$ for seven days. The cultured suspended cells were centrifuged, resuspended in RPMI 1\% FBS, and its concentration was adjusted to $1 \times 10^{6}$ cells $\mathrm{mL}^{-1}$.

\section{Colorimetric assay for cytotoxic activity analysis}

A non-radioactive colorimetric method based on lactate dehydrogenase (LDH) activity measurements was used to evaluate cytotoxic activity (Cytotoxicity Detection Kit, Roche Diagnostics, Mannheim, Germany). Mononuclear cells were obtained by centrifuging the spleen cell suspension on a FicollHypaque gradient (Sigma-Aldrich, St. Louis, United States of America), followed by incubation on glass Petri dishes for $90 \mathrm{~min}$ at $37^{\circ} \mathrm{C}$ to remove the adherent cells. The non-adherent cells were gently recovered from the Petri dishes and resuspended in RPMI 1\% FBS adjusted to a cell density of $1 \times 107$ cell mL-1. Next, $100 \mu \mathrm{L}$ of the non-adherent cell suspension (effectors) was dispensed into a "U"-bottomed 96well microtiter plate with $100 \mu \mathrm{L}$ of the target cell suspension (Yac.1) at a concentration of $1 \times 106$ cell mL-1 (effector to target ratio 50:1). Maximal lysis of target cells was determined by adding $100 \mathrm{~mL}$ of Triton X solution (Sigma-Aldrich, St. Louis, United 
States of America). Spontaneous lysis of Yac.1 cells was determined by incubation with RPMI 1\% FBS. Background control was also maintained with RPMI $1 \%$ FBS, without cells. After $4 \mathrm{~h}$ of incubation at $37^{\circ} \mathrm{C}$ and $5 \% \mathrm{CO}_{2}$, the plate was centrifuged for $10 \mathrm{~min}$ at $1500 \mathrm{rpm}$ and $50 \mu \mathrm{L}$ of the supernatant was carefully removed from each well and transferred into a 96-well flat-bottomed microtiter plate (Nunc A/S, Roskildwe, Denmark). LDH activity was quantified using $50 \mu \mathrm{L}$ of a Diaphorase/NAD + mixture and a dye solution containing iodo tetrazolium chloride. Sodium lactate was added to each well and incubated for $30 \mathrm{~min}$ at room temperature away from light. The absorbance was read at $492 \mathrm{~nm}$ (Thermo plate TP-reader). The percentage of specific lysis was calculated according to the following formula: cytotoxicity $(\%)=\{[($ absorbance of the mixture of target and effector cells - absorbance of control effector cells) - absorbance of spontaneous lysis control]/(absorbance of maximal lysis control absorbance of spontaneous lysis control) $\} \times 100$. Data are presented as means \pm standard deviation. Before cytotoxicity calculation, all absorbance values were subtracted from the mean value of the background control.

The cytotoxic assay of NK activity measures the ability of non-adherent spleen cells to kill Yac.1 target cells. This effect is attributed to NK cells because these cells are able to kill the Yac. 1 target cells without prior contact $[13,14]$.

\section{Statistical Analysis}

Statistical analysis was performed utilizing the GraphPad Instat software (San Diego, California, USA). One-way analysis of variance (ANOVA) and Tukey-Kramer tests were employed. Differences were considered significant when the probability of error was lower than $5 \%(\mathrm{p} \leq 0.05)$.

\section{RESULTS}

Figure 1 presents the cytotoxicity of nonadherent spleen cell suspension from experimental groups of mice treated with the ethanolic extract for seven or 14 days. Treatment with the ethanolic extract of C. multijuga bark for seven days (Figure 1A) increased the NK activity in Ehrlich tumorbearing mice $(21.20 \pm 8.89)$ compared to the control group $(3.14 \pm 2.71 ; \mathrm{p}<0.05)$ and $C$. multijuga group $(5.04 \pm 6.07 ; \mathrm{p}<0.05)$. However, this effect was not maintained in the groups treated for 14 days (Figure 1B) (Control: $6.02 \pm 6.98$, Ehrlich: $4.82 \pm 7.72, C$. multijuga: $2.07 \pm 2.10$, Ehrlich/C. multijuga: $2.01 \pm 1.63$; $\mathrm{p}>0.05)$.

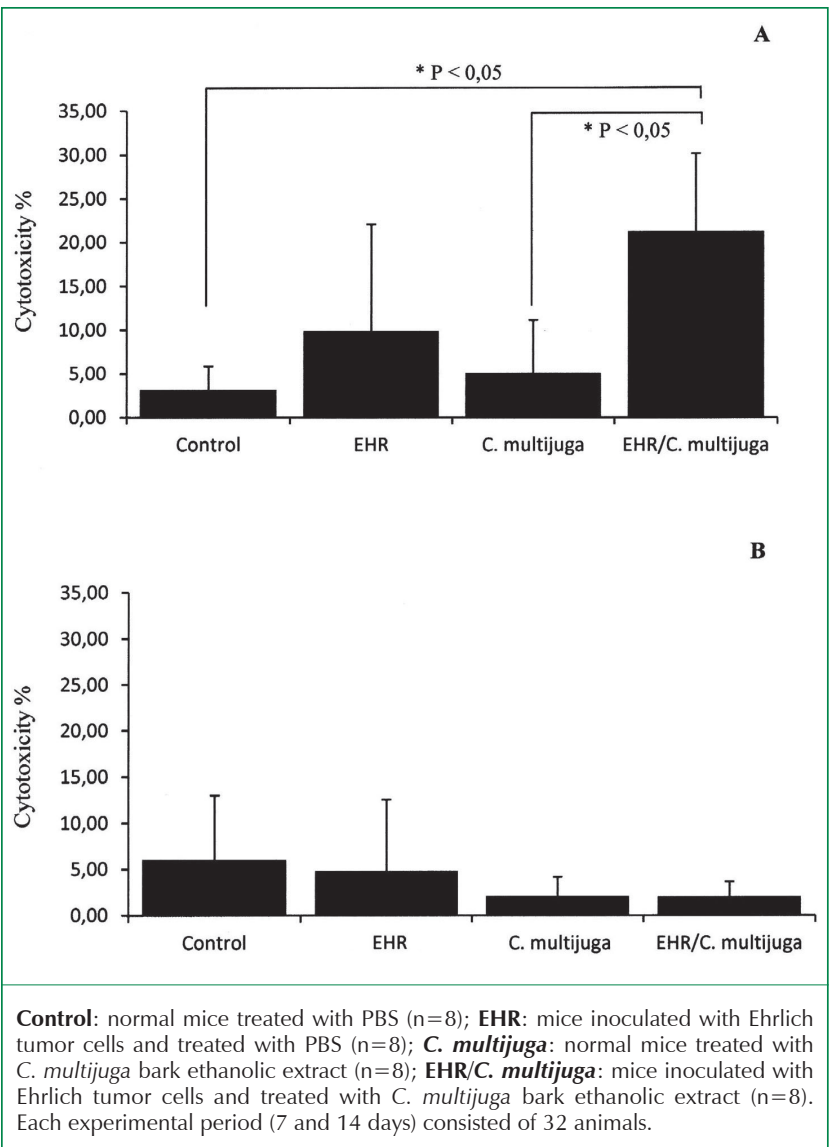

Figure 1. Percentage of cytotoxicity of natural killer activity from the culture of non-adherent spleen cells of Ehrlich tumorbearing mice after oral treatment with Copaifera multijuga bark ethanolic extract $\left(200 \mathrm{mg} \mathrm{kg}^{-1}\right)$ for 7 (A) or 14 days (B). The cytotoxic activity from non-adherent spleen effector cells against Yac. 1 target cells (effector to target ratio 50:1) was measured using an LDH Cytotoxicity Detection Kit. Data are presented as mean \pm standard deviation and were analyzed by ANOVA and Tukey test.

\section{DISCUSSION}

NK cells are important innate immune effector cells that provide rapid response to tumor and virusinfected cells [16]. Their importance is underscored by the fact that patients with NK cell deficiency suffer from severe recurring systemic and life-threatening infections [16]. Strikingly, the high cytotoxic activity of peripheral blood NK cells is associated with $10 \%$ lower incidence of tumors in men and $4 \%$ in women, and their infiltration of certain tumor tissues is an indicator of better disease prognosis [16]. In addition, NK cells that infiltrate tumors may prevent tumor metastasis and lymphatic invasion [13]. 
It is well known that the current treatments for cancer, such as chemotherapy and radiotherapy, induce immunosuppression in patients, decreasing immune function or causing dysfunction in immune cells such as cytotoxic T-lymphocytes and NK cells $[14,17]$. NK cells or their precursors are highly sensitive to in vivo treatment with cyclophosphamide, a standard chemotherapeutic agent, with reduction of NK cell activity in mice [13]. In this way, promotion of NK cell activation and proliferation is an emerging strategy in cancer immunotherapy, mainly because NK cells can lyse tumor cells without prior activation [15]. Furthermore, NK cells produce and secrete potent immunoregulatory cytokines, particularly IFN- $\gamma$, which increases cell reactivity and activates macrophages against the tumor cells [18].

In the present study, the ethanolic extract of $C$. multijuga bark was used to stimulate the immune response of mice, enhancing or potentiating the host's defense mechanism to inhibit tumor growth. Immunomodulation through natural substances may be considered as an alternative for prevention and cure of neoplastic diseases [17]. Immunomodulators may activate cytotoxic effector cells, such as cytotoxic T-lymphocytes, NK cells, and macrophages to kill the tumor cells without harming the normal host cells $[14,17]$.

Previous study by our group demonstrated that the ethanolic extract of $C$. multijuga bark can affect Ehrlich tumor cells, reducing their viability in vitro as well as their development in vivo, reducing tumor mass to $45 \%$, and increasing the production of IL12 p70, TNF- $\alpha$, and IFN- $\gamma$ in Con A or SAC-stimulated spleen cell culture supernatants [9]. C. multijuga bark ethanolic extract also increased the antioxidant capacity of the liver, increased catalase, reduced glutathione and glutathione-S-transferase activities, and decreased the levels of lipid peroxidation [19]. Results of the present study corroborate previous data $[9,19]$, showing that the immunomodulatory effect of $C$. multijuga on Ehrlich tumor-bearing mice is also a consequence of NK cell activity stimulation.

The use of medicinal plants for therapeutic purposes is now spread worldwide [20]. Several herbal preparations used in the indigenous system of medicine are known to boost the immune system [14]. Within this context, C. multijuga is an interesting option because of its documented medicinal effects such antimicrobial, antinociceptive, anti-inflammatory, wound-healing, antifungal, antiparasitic, and antitumor properties $[1,5,7-9,20]$. These activities are attributed to the presence of sesquiterpene and diterpene metabolites [20,21].

Although studies associating the biological response of $C$. multijuga sesquiterpene and diterpene metabolites with the activity of NK cells are lacking, some authors described that the activity of NK cells can be improved by sesquiterpenes from Artemisia annua L. [15], Vernonia cinerea L. [14, 17], and Zanthoxylum rhoifolium L. [2].

Artemisinin is a sesquiterpene lactone extracted from the plant of sweet wormwood (A. annua $\mathrm{L}$ ) and is a Chinese traditional medicine that has been used in the treatment of malaria [15]. Artemisinin also causes the apoptosis of various cancer cells such as those of the colon, breast, lung, and pancreas, because it reacts with heme or free iron, generating cytotoxic radicals that induce oxidative damage in these cells [15]. Houth et al. [15] demonstrated that artemisinin significantly enhances NK cell activity through granule exocytosis via the stimulation of signaling molecules of NK cell activating receptor.

Silva et al. [18] investigated the antitumor properties of the volatile oil from $Z$. rhoifolium leaves and some terpenes ( $\alpha$-humulene, $\beta$-caryophyllene, $\alpha$-pyrene, and $\beta$-pyrene) in vitro and in vivo using the Ehrlich ascites tumor model. The volatile oil had significant activity against the Ehrlich ascites tumor at a dose of $20 \mathrm{mg} \mathrm{kg}^{-1}$, increasing survival of tumor-bearing mice to $80 \%$; whereas survival of mice treated with $20 \mathrm{mg} \mathrm{kg}^{-1}$ of $\beta$-caryophyllene presented an increase of $31 \%$ [18]. The same response profile was observed, with half maximal inhibitory concentration $\left(\mathrm{IC}_{50}\right.$ ) values of $37 \mu \mathrm{g} \mathrm{mL}^{-1}$ for volatile oil and $102 \mu \mathrm{g} \mathrm{mL}^{-1}$ for $\beta$-caryophyllene [18]. The authors also demonstrated that treatment of tumor-bearing mice with $20 \mathrm{mg} \mathrm{kg}^{-1}$ of volatile oil or $\beta$-caryophyllene induced higher levels of splenic NK cell activity [18]

Vernolide-A is a sesquiterpene lactone present in the plant $V$. cinerea, which has many therapeutic uses in traditional medicine worldwide $[14,17]$. Its antioxidant, immunomodulatory, chemoprotective, and radioprotective effects in mice have been reported $[14,17]$. Administration of vernolide-A enhanced NK cell activity, as well as augmented antibody-dependent cellular cytotoxicity and antibody-dependent complement-mediated cytotoxicity in Ehrlich ascites tumor-bearing mice [17] and in B16F-10 metastatic melanoma-bearing mice [14]. In both situations, the increase in NK cell activity was associated with the up-regulation of IL-2 and IFN- $\gamma$ cytokines $[14,17]$.

The studies of Silva et al. [18], Pratheeshkumar and Kuttan [14, 17], and Houth et al. [15] support the 
enhancement in the NK activity from the culture of non-adherent spleen cells of Ehrlich tumor-bearing mice after treatment with the ethanolic extract of C. multijuga bark observed in this study; increased pro-inflammatory cytokines, such IFN- $\gamma$, was shown to be the mechanism in a previous study [9]. IFN- $\gamma$ is produced by $\mathrm{T}$ lymphocytes, NK cells, macrophages, and neutrophils and has receptors on virtually all cell types in the body [17]. Increased production of IFN- $\gamma$ is typically associated with an effective host defense against intracellular pathogens and cancer [17].

Immunomodulatory effects are also attributed to phenolic compounds and flavonoids [22-24]. Pereira et al. [25] evaluated the antioxidant effects of $C$. multijuga bark ethanolic extract and observed a higher concentration of phenolic compounds, such as epicatechin and epiafzelechin-condensed tannins. Increased NK activity observed in this study may be a consequence of the condensed tannins present in $C$. multijuga extract since condensed tannins upregulate NK cell response [22,23].

Although the improvement in NK activity seems to be opposite to the anti-inflammatory effect of copaiba, it is important to note that the biological effect of the plant extract reflects the complexity of the compounds and their different mechanisms of action $[9,26]$. Thus, reduction of Ehrlich tumor growth may be a result of the association of the anti-inflammatory and immunostimulatory effects.

In fact, during the Ehrlich tumor growth, the progressive reduction of NK cell activity was related to the presence of prostaglandin $\mathrm{E}_{2}$ [13]. In addition, copaiba extracts appear to be similar to non-steroidal anti-inflammatory drugs, involving inhibition of cyclooxygenase and lipoxygenase pathways [9,27]. Thus, the extract inhibits the influx of neutrophils and macrophages into the tumor microenvironment, reducing the angiogenic factors important for tumor growth, as well as increasing the antitumor immune response, improving the NK cells activity and reducing the immunosuppressive factors such as prostaglandins $[9,13,27]$.

An ideal anti-cancer drug should show killing activity only against cancer cells with no toxic effects on normal and immune system cells [15].
In this respect, compounds from $C$. multijuga may be ideal, owing to their high effectiveness and low toxicity. Albiero et al. [9] showed that ethanolic and ethyl acetate extracts from $C$. multijuga bark are not toxic to normal spleen cells in vitro at $0.5 \mathrm{mg} \mathrm{mL}^{-1}$ and $0.25 \mathrm{mg} \mathrm{mL}^{-1}$ concentrations. Furtado et al. [28] showed no genotoxic effects in both in vitro and in vivo micronucleus assays using different concentrations of C. multijuga leaf extracts and oleoresin. No genotoxic effects were also observed by Alves et al. [29] in their micronucleus tests with C. multijuga oleoresin.

Thus, the results of this study corroborate with previous reports regarding the effects of copaiba, showing that the compounds may be potent anticancer drugs that act not only to inhibit cancer development but also to activate antitumor immune response. Although oleoresin is the most used form of copaiba, it is important to consider that not all trees produce the oleoresin [6], and other forms, such extracts from the bark, may also be used since they also have bioactive compounds.

It can be concluded that the NK activity from the culture of non-adherent spleen cells of Ehrlich tumorbearing mice was enhanced by treatment with the ethanolic extract of $C$. multijuga bark for seven days. Additional studies are necessary to identify which compounds may have produced this effect and which cellular mechanisms are involved.

\section{NOTES}

Funding

This study did not receive financial support from outside sources.

Conflicts of interest disclosure

The authors declare no competing interests relevant to the content of this study.

Authors' contributions

All the authors declare to have made substantial contributions to the conception, or design, or acquisition, or analysis, or interpretation of data; and drafting the work or revising it critically for important intellectual content; and to approve the version to be published.

Availability of data and responsibility for the results

All the authors declare to have had full access to the available data and they assume full responsibility for the integrity of these results.

\section{REFERENCES}

1. Tobouti PL, Martins TCA, Pereira TJ, Mussi MCM. Antimicrobial activity of copaíba oil: A review and a call for further research. Biomed Pharmacother. 2017;94:93-9. http://dx.doi.org/10.1016/j.biopha.2017.07.092 
2. Ricardo LM, Dias BM, Mügge FLB, Leite VV, Brandão MGL. Evidence of traditionality of Brzilian medicinal plants: The case studies of Stryphnodendron adstringens (Mart.) Coville (barbatimão) barks and Copaifera spp. (copaíba) oleoresin in wound healing. J Ethnopharmacol. 2018;219:319-36. https://dx.doi.org/10.1016/j.jep.2018.02.042

3. Sultana S, Asif HM, Nazar HMI, Akhtar N, Rehman JU, Rehman RU. Medicinal Plants Combating Against Cancer - a Green Anticancer Approach. Asian Pac J Cancer Prev. 2014;15(11):4385-94. http://dx.doi.org/10.7314/APJCP.2014.15. 11.4385

4. BRASIL. Lei $n^{\circ}$ 71, de 2 de setembro de 2013. Diário Oficial da República, Brasília, DF, 2 set. 2013. Série 1, p. 5439.

5. Albuquerque KCO, Veiga ASS, Silva JVS, Brigido HPC, Ferreira EPR, Costa EVS, Marinho AMR, Percário S, Dolabela M.F. Brazilian Amazon Traditional Medicine and the Treatment of Difficult to Heal Leishmaniasis Wounds with Copaifera. Evid Based Complement Alternat Med. 2017;2017:8350320. http://dx.doi.org/10.1155/2017/8350320

6. Trindade R, Silva JK, Setzer WN. Copaifera of the Neotropics: A Review of the Phytochemistry and Pharmacology. Int J Mol Sci. 2018;19(5):1511-44. https://doi.org/10.3390/ijms19051511

7. Diefenbach AL, Muniz FWMG, Oballe HJR, Rosing CK. Antimicrobial activity of copaíba oil (Copaifera ssp.) on oral pathogens: Systematic review. Phytother Res. 2018;32:586-96. https://doi.org/10.1002/ptr.5992

8. Ghizoni CVC, Ames APA, Lameira OA, Amado CAB, Nakanishi ABS, Bracht L, Natali MRM, Peralta RM, Bracht A, Comar JF. Anti-inflammatory and Antioxidant Actions of Copaíba Oil Are Related to Liver Cell Modifications in Arthritic Rats. J Cell Biochem. 2017;118:3409-23. https://doi.org/10.1002/jcb.25998

9. Albiero LR, Nery EF, Dalazen JC, Kelly TO, Pereira DL, Sinhorin VDG, Kaneno R, Castoldi L. Ethanolic extracts of Copaifera Multijuga Inhibits the Subcutaneous Growth of Ehrlich Carcinoma in Swiss Mice. IOSR-JPBS. 2016;11(5): 30-8. http://doi.org/10.9790/3008-1105033038

10. Cassali GD, Silva AE, Santos FGA. Marcadores de proliferação celular na avaliação do crescimento do tumor sólido e ascítico de Ehrlich. Arq Bras Med Vet Zootec. 2006;58:658-61. http://dx.doi.org/10.1590/S0102-09352006000400030

11. Calixto-Campos C, Zarpelon AC, Corrêa M, Cardoso RDR, Pinho-Ribeiro FA, Cecchini R, Moreira EG, Crespigio J, Bernardy CCF, Casagrande R, Verri Jr W. The Ehrlich's tumor induces pain-like behavior in mice: a novel model of cancer pain for pathophysiological studies and pharmacological screening. Biomed Res Int. 2013;2013:624815. http:// dx.doi.org/10.1155/2013/624815

12. Frajacomo FTT, Padilha CS, Marinello PC, Guarnier FA, Cecchini R, Duarte JAR, Deminice R. Solid Ehrlich carcinoma reproduces functional and biological characteristics of cancer cachexia. Life Sci. 2016;162:47-53. https://doi.org/10.1016/j. lfs.2016.08.009

13. Valadares MC, Klein SI, Guaraldo AMA, Queiroz MLS. Enhancement of natural killer cell function by titanocenes in mice bearing Ehrlich ascites tumour. Eur J Pharmacol. 2003;473:191-6. https://doi.org/10.1016/S0014-2999(03)01967-8

14. Pratheeshkumar P, Kuttan G. Effect of vernolide-A, a sesquiterpene lactone from Vernonia cinereal L., on cell-mediated immune response in B16F-10 metastatic melanoma-bearing mice. Immunopharmacol Immunotoxicol. 2011;33(3):533-8. https://doi.org/10.3109/08923973.2010.547501

15. Houh YK, Kim KE, Park S, Hur DY, Kim S, Kim D, Bang SI, Yang Y, Park HJ, Cho D. The Effects of Artemisinin on the Cytolytic Activity of Natural Killer (NK) Cells. Int J Mol Sci. 2017;18(7):1600-11. https://doi.org/10.3390/ijms 18071600

16. Koch J, Steinle A, Watzl C, Mandelboim O. Activiting natural cytotoxicity receptors of natural killer cells in cancer and infection. Trends Immunol. 2013;34(4):182-91. http://dx.doi.org/10.1016/j.it.2013.01.003

17. Pratheeshkumar P, Kuttan G. Modulation of cytotoxic T lymphocyte, natural killer cell, antibody-dependent cellular cytotoxicity, and antibody-dependent complement-mediated cytototxicity by Vernonia cinereal L. and vernolide-A in $\mathrm{BALB} / \mathrm{c}$ mice via enhanced production of cytokines IL-2 and IFN- $\gamma$. Immunopharmacol Immunotoxicol. 2012;34(1): 46-55. https://doi.org/10.3109/08923973.2011.574703

18. Silva SL, Figueiredo PMS, Yano T. Chemotherapeutic potencial of the volatile oils from Zanthoxylum rhoifolium Lam leaves. Eur J Pharmacol. 2007;576:180-8. https://doi.org/10.1016/j.ejphar.2007.07.065

19. Cunha APS, Baldissera L, Pereira DL, Albiero LR, Castoldi L, Sinhorin AP, Sinhorin VDG. Evaluation of the antioxidant potencial of Copaifera multijuga in Ehrlich tumor-bearing mice. Acta Amazon. 2019;49(1):41-7. https://dx.doi. org/10.1590/1809-4392201800672

20. Botelho NM, Corrêa SC, Lobato RC, Teixeira RKC, Quaresma JAS. Immunohistochemistry of the uterine cervix of rats bearing the Walker 256 tumor treated with copaíba balsam. Acta Cir Bras. 2013;28(3):185-9. http://dx.doi.org/10.1590/ S0102-86502013000300005

21. Dias FGG, Jorge AT, Pereira LF, Furtado RA, Ambrósio SR, Bastos JK, Ramos SB, Chahud F, Dias LGGG, Honsho CS, Tavares DC. Use of Copaifera multijuga for acute corneal repair after chemical injury: A clinical, histopathological and toxicogenetic study. Biomed Pharmacother. 2017;96:1193-98. https://doi.org/10.1016/j.biopha.2017.11.099

22. Chen L, Wei Y, Zhao S, Zhang M, Yan X, Gao X, Li J, Gao Y, Zhang A, Gao Y. Antitumor and immunomodulatory activities of total flavonoids extract from persimmon leaves in $\mathrm{H}_{22}$ liver tumor-bearing mice. Sci Rep. 2018;8:10523-34. https://doi.org/10.1038/s41598-018-28440-8

23. Holderness J, Jackiw L, Kimmel E, Kerns H, Radke M, Hedges JF, Petrie C, McCurley P, Glee PM, Palecanda A, Jutila MA. Select Plant Tannins Induce IL-2R $\alpha$ Up-Regulation and Augment Cell Division in $\gamma \delta \mathrm{T}$ Cells. J Immunol. 2007;179:6468-78. https://doi.org/10.4049/jimmunol.179.10.6468 
24. Lisanti A, Formica V, Ianni F, Albertini B, Marinozzi M, Sardella R, Natalini B. Antioxidant activity of phenolic extracts from different cultivars of Italian onion (Allium cepa) and relative human immune cell proliferative induction. Pharm Biol. 2016;54(5):799-806. https://doi.org/10.3109/13880209.2015.1080733

25. Pereira DL, da Cunha APS, Cardoso CRP, da Rocha CQ, Vilegas W, Sinhorin AP, Sinhorin VDG. Antioxidant and hepatoprotective effects of ethanolic and ethyl acetate stem bark extracts from Copaifera multijuga (Fabaceae) in mice. Acta Amazon. 2018;48(4):348-58. http://dx.doi.org/10.1590/1809-4392201704473

26. Brito NMB, Brito MVH, Carvalho RKV, Moura LTM, Matos B, Lobato RC, Correa SC, Brito RB. The effect of copaíba balsam on Walker 256 carcinoma inoculated into the vagina and uterine cervix of female rats. Acta Cir Bras. 2010;25: 176-80. http://dx.doi.org/10.1590/S0102-86502010000200010

27. Lucca LG, Matos SP, Kreutz T, Teixeira HF, VeigaJr VF, Araújo BV, Limberger RP, Koester LS. Anti-inflammatory effetct from a hydrogel containing nanoemulsified copaíba oil (Copaifera multijuga Hayne). AAPS PharmSciTech. 2017;19(2):522-30. http://dx.doi.org/10.1208/s12249-017-0862-6

28. Furtado RA, Oliveira PF, Senedese JM, Ozelin SD, Souza LDR, Leandro LF, Oliveira WL, Silva JJM, Oliveira LC, Rogez H, Ambrosio SR, Veneziani RCS, Bastos JK, Tavares DC. Assessment of genotoxic activity of oleoresins and leaves extracts of six Copaifera species for prediction of potencial human risks. J Ethnopharmacol. 2018;221:119-25. https://doi.org/10.1016/j.jep.2018.04.002

29. Alves JM, Senedese JM, Leandro LF, Castro PT, Pereira DE, Carneiro LJ, Ambrósio SR, Bastos JK, Tavares DC. Copaifera multijuga oleoresin and its constituent diterpene (-)-copalic acid: Genotoxicity and chemoprevention study. Mutat Res Gen Tox En. 2017;819:26-30. https://doi.org/10.1016/j.mrgentox.2017.05.001 